\title{
Credibility of Different Sources and Channels of Information Perceived by Tribal Livestock Owners in Sirohi District of Rajasthan, India
}

\author{
Rohitash Kumar $^{1 *}$, Tikam C. Goyal ${ }^{1}$, Devi Singh Rajput ${ }^{2}$ and Rahul Choudhary ${ }^{3}$ \\ ${ }^{1}$ Department of Veterinary and Animal Husbandry Extension Education, College of \\ Veterinary and Animal Science, Navania, Vallabhnagar, Udaipur-313601, India \\ ${ }^{2}$ Department of Veterinary and Animal Husbandry Extension Education, College of \\ Veterinary and Animal Science, Bikaner-334001, India \\ ${ }^{3}$ Department of Veterinary and Animal Husbandry Extension Education, Mahatma Jyotiba \\ Fule College of Veterinary and Animal Science, Chomu, Jaipur, 303702, India
}

*Corresponding author

\section{A B S T R A C T}

\begin{tabular}{|l|}
\hline K e y w o r d s \\
$\begin{array}{l}\text { Credibility, Sources and } \\
\text { channels of information, } \\
\text { Tribal livestock owners }\end{array}$ \\
\hline Article Info \\
\hline $\begin{array}{l}\text { Accepted: } \\
\text { 12 August } 2018 \\
\text { Available Online: } \\
\text { 10 September } 2018\end{array}$ \\
\hline
\end{tabular}

Livestock owners may come across large number of sources and channels of information but pursue only a few of them for seeking knowledge and information. The data was collected from 120 tribal livestock owners' families of Pindwara and Abu road Tehsils of Sirohi district. It was observed that veterinary hospitals, farmer meeting and demonstration were perceived as most credible channels of information by the livestock owners with MPS 81.94, 73.33 and 70.00 respectively. This was followed by training MPS 67.22, field trip MPS 62.77 and exhibition MPS 61.94. Further the TV MPS 57.20, radio MPS 55.83 and Newspaper MPS 37.75 were trusted by relatively less number of livestock owners of the study area. The study was recommended that the measures can be taken by the concern agencies to further improve the access and availability of more trustworthy and competent sources and channels in the area which was used by the livestock owners.

\section{Introduction}

India's livestock sector is one of the largest in the world. It has 56.70 per cent of world's buffalo, 12.50 per cent cattle, 20.40 per cent small ruminants and 3.10 per cent poultry. In the year 2010-11 livestock comprised 4.0 per cent of GDP and 26.0 per cent of agricultural GDP. With an estimated 86.80 million tones of annual milk production from animals managed by nearly 70 million farmers, India is the top-most milk producing country in the world. The number of animals in the milk in cows and buffaloes has increased from 77.04 million to 80.52 million showing a growth of 4.51 per cent. (Anonymous, 2012). India is an agrarian country and agriculture is the backbone of Indian economy.

Livestock sector is an integral part of the agricultural system in India and contributes significantly to the GDP. It ensures food and nutritional security on one hand and provides income and employment opportunities on the other hand (Ravikumar and Mahesh, 2006; Borah and Halim, 2014). 
The present era is the age of communication. The present system of transfer of technology, which is highly compartmentalized, has several inherent weaknesses. To meet the needs of "Information Hungry" livestock owners and women and youth engaged in livestock farming, the present extension system has to be geared up. The information is also a critical input and as important as other key inputs such as credit, Housing, breeding, scientific feeding and proper management of the livestock. Different sources and channels of livestock related information can play important role to meet this requirement. Although farmers may have a number of information sources and channels available to them, they pursue only a few (Aboyade 1987, Gunawardana and Sharma 2006). The use of information by a user is defined by demand of information and disposition of the information channel (Lee 1996). Information sources must be reliable, credible and user-friendly (Das 2012). Farmers would be benefitted to a greater extent if information centres were located in rural areas supported with complete information and communication gadgets (Aina, 2007). The Quality, timeliness and trustworthiness of information are the important criteria to meet the needs and expectations of the farmers (Mittal and Tripathi 2009). It is of utmost importance to know the credibility of different sources and channels that are utilized by the livestock owners to seek information. Credibility was the extent to which a communication source was preferred as trustworthy and important by receivers of the message.

\section{Materials and Methods}

The present study was conducted in Sirohi district of Rajasthan. Two Tehsils Abu Road and Pindwara were selected for the study on the basis of highest population of Grasia tribe. From comprehensive list of all the villages, under the respective tehsil was prepared in discussion with patwaries, tehsildar, Atal Seva Kendra, secondary sources, etc. Eight villages were selected randomly from two tehsil. Total 15 Garasia families from each selected village were selected randomly as respondents. Thus, in total 120 Garasia tribal families who possess livestock for their livelihood was selected as respondents for the purpose of present study. Data were collected by the investigator through personal interview technique with the help of semi structured interview schedule and the collected data were tabulated and inferences were drawn by using statistical measures. The level of credibility of different sources and channels of information as perceived by the tribal livestock owners was analyzed by using a 3 point continuum i.e. most credible, credible and least credible with their respective scores as 3,2, and 1 . In order to find out the credibility in various areas related to seek information, the mean score (MS) and mean percent score (MPS) for each source and channel was calculated.

\section{Results and Discussion}

\section{Credibility of various sources of information}

Three cosmopolite sources i.e. scientist from KVK, veterinary officer and LSA were perceived as most credible sources by livestock owners with MPS 90.00, 86.11 and 85.80, respectively (Table 1 ).

It was followed by progressive livestock owners with MPS 79.16 and local leaders MPS 75.83. Further the extension officer MPS 73.05, Sarpanch MPS 70.27 and cooperative personnel were trusted by relatively less number of livestock owners of the study area for information pertaining to livestock management practices. Among localite sources viz. neighbours MPS 39.16, friends MPS 34.15, and relatives MPS 33.88, were perceived as less competent and less reliable 
for seeking information by majority of the respondents. It is suggested that efforts should be made to use friends and neighbour to communicate animal husbandry related information for the livestock owners in the study area.

The rank order correlation value between the ranks accorded by tribal livestock owners of Pindwara and Abu road tehsils was found to be 0.87 , which is statistically significant.

This infers that the respondents of both the Tehsils have shown different ranking pattern to various sources with respect to their credibility different sources of information.

The results are in line with the results of Rai and Chobey (1985) who found that SMS of agricultural university was the most credible source of information to the farmers.

Kumar (2001) also reported that agricultural scientists were highly credible source of information perceived by wheat growers.
Credibility of various channels of information

Credibility of information channels affects the adoption of improved animal husbandry practices by livestock owners. Credibility refers to perceived trustworthiness and expertise accorded to a channel by its audience at any given time. A perusal of the Table 2 revealed that three channels of information i.e. veterinary hospitals, farmer meeting and demonstration were perceived as most credible channels of information by the livestock owners with MPS 81.94, 73.33 and 70.00 respectively. It was followed by training MPS 67.22 field trip MPS 62.77 and exhibition MPS 61.94. Further the TV MPS 57.20, radio MPS 55.83 and Newspaper MPS 37.75 were trusted by relatively less no of livestock owners of the study area. The other channels of information i.e. film show MPS 36.11 and traditional media MPS 34.40 were perceived as much less reliable for getting information about livestock management practices by the respondents.

Table.1 Credibility of different sources of information as perceived by livestock owners

\begin{tabular}{|l|l|l|l|l|l|l|l|}
\hline $\begin{array}{l}\text { S. } \\
\text { No. }\end{array}$ & $\begin{array}{l}\text { Information } \\
\text { Sources }\end{array}$ & $\begin{array}{l}\text { MIPS } \\
\text { (Pindwara) }\end{array}$ & Rank & $\begin{array}{l}\text { MIPS } \\
\text { (Aburoad) }\end{array}$ & Rank & $\begin{array}{l}\text { Total } \\
\text { MIPS }\end{array}$ & Rank \\
\hline 1. & $\begin{array}{l}\text { Scientist from } \\
\text { KVK/university }\end{array}$ & 85 & III & 91.66 & I & 90 & I \\
\hline 2. & Vety. Officer & 88.33 & I & 87.22 & II & 86.11 & II \\
\hline 3. & LSA & 82.20 & IV & 86.11 & III & 85.80 & III \\
\hline 4. & $\begin{array}{l}\text { Progressive livestock } \\
\text { Owner }\end{array}$ & 75.50 & V & 78.33 & IV & 79.16 & IV \\
\hline 5. & Local leader & 85.55 & II & 76.11 & V & 75.83 & V \\
\hline 6. & Extension officer & 72.22 & VII & 73.88 & VI & 73.05 & VI \\
\hline 7. & Sarpanch & 73.33 & VI & 65.00 & VIII & 70.27 & VII \\
\hline 8. & Co-operative personal & 69.44 & VIII & 67.22 & VII & 68.33 & VIII \\
\hline 9. & Neighbours & 34.40 & XI & 34.44 & X & 39.16 & IX \\
\hline 10. & Friends & 37.75 & IX & 33.33 & XI & 34.15 & X \\
\hline 11. & Relatives & 35.00 & X & 40.55 & IX & 33.88 & XI \\
rs $=0.87^{\text {s }}$ & & & & & & & \\
\hline
\end{tabular}


Table. 2 Credibility of different channels of information as perceived by livestock owners

\begin{tabular}{|l|l|l|l|l|l|l|l|}
\hline $\begin{array}{l}\text { S. } \\
\text { No }\end{array}$ & Channels & $\begin{array}{l}\text { MIPS } \\
\text { (Pindwara) }\end{array}$ & Rank & $\begin{array}{l}\text { MPS } \\
\text { (Abu } \\
\text { road) }\end{array}$ & Rank & $\begin{array}{l}\text { Total } \\
\text { MPS }\end{array}$ & Rank \\
\hline 1. & Vety. hospital & 81.11 & I & 82.77 & I & 81.94 & I \\
\hline 4. & Farmer's meeting & 72.77 & II & 71.65 & III & 73.33 & II \\
\hline 6. & Demonstration & 68.33 & IV & 61.11 & V & 70 & III \\
\hline 2. & Training & 70.55 & III & 73.88 & II & 67.22 & IV \\
\hline 9. & Field trip & 65.00 & V & 63.85 & IV & 62.77 & V \\
\hline 3. & Exhibition & 62.75 & VI & 60.55 & VI & 61.94 & VI \\
\hline 5. & T.V & 57.75 & VII & 57.40 & VIII & 57.20 & VII \\
\hline 8. & Radio & 36.11 & IX & 39.44 & IX & 55.83 & VIII \\
\hline 7. & News paper & 55 & VIII & 53.85 & VII & 37.75 & IX \\
\hline $\mathbf{1 0 .}$ & Film show & 33.33 & XI & 37.20 & X & 36.11 & X \\
\hline 11. & Traditional media & 35 & X & 35.55 & XI & 34.40 & XI \\
rs $=0.96 *$ & & & & & & & \\
\hline
\end{tabular}

The rank order correlation value between the ranks accorded by tribal livestock owners of Pindwara and Abu road Tehsils was found to be 0.96 , which was statistically significant at 5 percent level of significance. This infers that the respondents of Pindwara and Abu road tehsils have perceived the selected channels of information as the respect for seeking information.

The results are in line with the results of Singh and Prasad (1974) and Kumar (2001) who reported demonstration as highly credible channel of information perceived as by the farmers. Almost similar findings were reported by Pradeep and Rajkamal (2008) who reported that dairy entrepreneurs perceived technical experts as the most credible sources of information available them. It was followed by institutional sources like veterinary college and veterinary hospital.

It can be concluded that Scientists from KVK and Veterinary officers were perceived as most credible sources of information by livestock owners whereas friends and relatives were perceived least credible sources of information to seek information. Veterinary hospitals and farmer meeting were considered most credible while film show and traditional media were considered as least credible channels by the tribal livestock owners. Based on study results it is recommended that the access and availability of the more credible sources and channels be increased in the study area for getting quick and accurate information about animal husbandry aspects. It is recommended to establish a well-equipped information center. The center equipped with radio, television, different types of farm publication like leaflet, folder, pamphlet, flash cards and newspapers provide necessary information to the livestock owners in the area.

\section{References}

Aboyade BO 1987. The provision of information rural development. Ibadan: Fountain Publication. Adhiguru P, Birthal PS, Ganesh Kumar B, 2009. Strengthening Pluralistic Agricultural Information Delivery System in India. Agricultural Economics Research Review 22(1):71-79. 
Aina LO, 2007. Globalisation and Small Scale Farming in Africa: What role for Information Centres? World libraries and information congress $73^{\text {rd }}$ IFLA General conference and council. Durban, South Africa.

Anonymous. 2012. Animal Husbandry Statistics, Ministry of Statistics and Programme Implementation, Social Statistics Division, New Delhi.

Borah M and Halim RA. 2014. Dynamics and Performance of Livestock and Poultry Sector in India: A Temporal Analysis. Journal of Academia and Industrial Research. 3 (1): 1-9.

Das D, 2012. Sources of agricultural information among rural women: a village level study in Assam. International Journal of Economics and Research, Sept- Oct: 1-12.

Gunawardana A MA P G, Sharma VP, 2006. Information source credibility among tribal and non-tribal farmers. Rajasthan Journal of Extension Education 14:8285.

Kumar, A. 2001. Communication behaviour of wheat growing farmers in irrigated tract of Haryana. M.Sc. Thesis, CCS HAU, Hisar.

Lee MKO, 1996. Information access behaviour and expectation of quality: two factors affecting the satisfaction of users of clinical hospital information systems. Journal of Information Science 22(3):171-199.

Mittal S, Tripathi G, 2009. Role of Mobile Phone Technology in Improving Small Farm Productivity. Agricultural Economics Research Review 22: 45159.

Pradeep, C.A. and Rajkamal, P.J. 2008. Credibility of communication sources as perceived by the dairy entrepreneurs. $J$. Vet. Anim. Sci., 39: 60-61.

Rai, B.D. and Choubey, C.L. 1985. Credibility, usefulness and utilization of communication sources and channels as perceived by farmers. Maha. J. Extn. Edu., 4: 59-61.

Ravikumar RK and Mahesh C. 2006. Extension educational efforts by State Department of Animal Husbandry (SDAH), Tamil Nadu: SWOT analysis. Livestock Research for Rural Development, 18. Retrieved from http:// www.lrrd.org/lrrd18/9/ ravi18126.html.

Singh, N.P. and Prasad, C. 1974. Communication behaviour and source credibility perception of young farmers. Indian J. Extn. Edu., 10(1\&2): 53-58.

\section{How to cite this article:}

Rohitash Kumar, Tikam C. Goyal, Devi Singh Rajput and Rahul Choudhary. 2018. Credibility of Different Sources and Channels of Information Perceived by Tribal Livestock Owners in Sirohi District of Rajasthan, India. Int.J.Curr.Microbiol.App.Sci. 7(09): 1804-1808. doi: https://doi.org/10.20546/ijcmas.2018.709.219 